\title{
Encystment of the freshwater ciliate Pelagostrombidium fallax (Ciliophora, Oligotrichida) in laboratory culture
}

\author{
Helga Müller*
}

Limnological Institute, PO Box 5560, D-78434 Konstanz, Germany

\begin{abstract}
Pelagostrombidium fallax from surface waters of Lake Constance, Germany, was cultivated at $9^{\circ} \mathrm{C}$ with $R$ hodomonas $\mathrm{sp}$. as food. Flask-shaped resting cysts typical for oligotrich ciliates were frequently observed in the stock cultures. In batch culture experiments, encystment occurred at high and low food levels. Cyst formation ceased during phases of population growth, whereas enhanced encystment was recorded shortly after food had been reduced to low concentrations by ciliate grazing. In any situation, only a fraction of the population encysted.
\end{abstract}

KEY WORDS: Oligotrichida - Cyst Pelagostrombidium fallax Freshwaler plankton

\section{INTRODUCTION}

Oligotrich ciliates are important members of the microplankton in marine and fresh waters. Mass development of oligotrichs as a response to phytoplank ton blooms is a well-known phenomenon (e.g. Sorokin \& Paveljeva 1972, Smetacek 1984, Weisse et al. 1990). Much less is known on their survival strategies during periods of low food concentrations.

Resting cysts have been observed in several species of marine tintinnids (e.g. Reid \& John 1978, Paranjape 1980). These cysts remain attached inside the loricae and, therefore, can be unequivocally identified. In contrast, descriptions of resting cysts of non-loricate oligotrich ciliates are very rare, due to the difficulty of detecting and identifying such cysts in pelagic waters and sediments. Up to now, there has been evidence of cyst formation in only 3 species of this taxonomic group, all from the marine environment: Fauré-Fremiet (1948) observed that Strombidium oculatum living in small tide pools exhibits a circatidal rhythm of en- and excystment. The life cycle of this species has been studied in detail by Jonsson (1994). Reid (1987) found large numbers of flask-shaped cysts in sediment traps exposed in the

\footnotetext{
·E-mail: helga.mueller@uni-konstanz.de
}

western English Channel, which were interpreted as resting stages of Strombidium crassulum (see 'Discussion'). Kim \& Tanaguchi (1995) isolated flask-shaped cysts from sediment samples collected from the Pacific coast of Japan. Excystment was inducible by temperature increase, and the emerging ciliates were identified as Strombidium conicum. The present study is the first report on cyst formation in a non-loricate oligotrich ciliate from the freshwater environment.

As reviewed by Corliss \& Esser (1974), a large variety of different factors have been reported to induce encystment in protozoa, including deficiency of food and excess of food. Fenchel (1987) pointed to starvation as the most common stimulus which leads to encystment. Since encystment of Pelagostrombidium fallax might enable it to survive periods of low food abundance, the relationship between cyst formation of this oligotrich ciliate and prey concentration was examined and is reported here.

\section{MATERIALS AND METHODS}

Pelagostrombidium fallax (Zacharias 1896) Krainer, 1991 was isolated from surface waters of Lake Constance in March 1996. The species was identified by live observation and protargol staining according to Krainer (1991) 
and Foissner (1994). Stock cultures were maintained in sterile-filtered lake water at $9 \pm 1{ }^{\circ} \mathrm{C}$ with the cryptomonad Rhodomonas sp. as food. This Rhodomonas strain (26.80 from the algal culture collection in Göttingen, Germany) had a cell volume of $-320 \mu \mathrm{m}^{3}$ (Giani 1991) and a carbon content of $-35 \mathrm{pg} \mathrm{C}$ cell ${ }^{-1}$, using a conversion factor of $110 \mathrm{fg} \mathrm{C} \mu \mathrm{m}^{-3}$ (Strathmann 1967). Use of this conversion factor enabled direct comparison with data from Müller et al. (1991) on concentrations of potential ciliate prey in the surface waters of Lake Constance. Cultures were illuminated with white fluorescent light in a $12: 12 \mathrm{~h}$ light: dark cycle and at an irradiance of $-25 \mu \mathrm{E} \mathrm{m}^{-2} \mathrm{~s}^{-1}$. All cultures contained bacteria and heterotrophic nanoflagellates.

Cyst morphology was studied by light microscopy using unstained live cysts. Squashed cysts devoid of cytoplasm were used to examine colour and transparency of the cyst wall. Dimensions of live cysts were measured with a calibrated eyepiece micrometel. After vilal staining with the fluorochrome DAPI $(4,6$-diamidino-2phenylindole, $0.2 \mu \mathrm{g} \mathrm{ml}^{-1}$ final concentration), cysts were inspected by epifluorescence microscopy, with green and UV excitation. Some material was fixed with $2 \%$ glutaraldehyde and critical point dried for examination by scanning electron microscopy (SEM).

Experiments were performed in cell culture cluster dishes $\left(\operatorname{Costar}^{\circ}\right)$ under the light and temperature conditions described above. Parallel batch cultures of Pelagostrombidium fallax with Rhodomonas sp. as food were grown in 12 - or 24 -well clusters, with 3.5 or $2.5 \mathrm{ml}$ of culture fluid per well, respectively. To determine concentrations of motile ciliates, cysts and food algae, the entire contents of a well was removed and fixed with acid Lugol's solution. Counts were performed in Sedgewick-Rafter chambers ( $1 \mathrm{ml}$ volume). Algae were counted by scanning an appropriate number of squares to record at least 250 cells, and 2 to 3 entire chambers were scanned for motile ciliates and cysts. Experimental protocols are described in detail in the 'Results'

The growth rate $(\mu)$ of Pelagostrombidium fallax was determined over a period of exponential increase in numbers $(\mathrm{N})$ of ciliates with time $(t)$. From pooled data collected during this interval, a regression equation $(\log N=a+b t)$ was calculated. Initial $\left(N_{0}\right)$ and final $\left(N_{1}\right)$ cell numbers were obtained from this equation and the growth rate was calculated according to $\mu=$ $\left(\ln N_{i}-\ln N_{0}\right) t^{-1}$.

\section{RESULTS}

\section{Morphological features}

Cysts of Pelagostrombidium fallax were first detected in May 1996, about 6 wk after isolation of the species from the lake. They were attached to the bottom of culture dishes and predominantly located at the edges, which points to a thigmotactic reaction of individuals beginning to encyst. Figs. 1 \& 2 show a motile specimen and a cyst of $P$. fallax at the same magnification. Live cysts were $66 \pm 3 \mu \mathrm{m}$ long and $42 \pm 1 \mu \mathrm{m}$ wide $(n=30)$ and thus were slightly smaller than wellfed motile specimens (Fig. 1). The cysts had a very characteristic flask shape, with the aperture closed by a hyaline plug.

Morphological details of cysts are illustrated in Figs. 3 to 7 . Light microscopy revealed a colourless, transparent cyst wall which enclosed the cytoplasm of granular structure, without visible organelles (Fig. 3). The cyst surface was colonized by bacteria, as shown in Fig. 4 by epifluoresconce microscopy after vital DAPI staining. The cyst contents did not stain with DAPI. With green excitation, motile ciliates showed strong red autoriuorescence due to Rhodomonas sp. cells accumulated in their food vacuoles. No autofluorescence was observed in the cysts, which indicates that food algae were completely digested prior to encystment. The cyst contents stained dark brown with acid Lugol's solution, but remained unstained after treatment with protargol. SEM micrographs show the cyst wall to be ornamented with spines, which were 3 to $4 \mu \mathrm{m}$ long and $\sim 0.2 \mu \mathrm{m}$ wide and were anchored on the surface with fine fibres (Figs. 5 to 7). Detritus and bacteria attached to the cyst wall are also seen on these illustrations. A schematic drawing of a cyst is presented in Fig. 8.

\section{Dynamics of cyst production}

The dynamics of cyst production was studied in batch cultures. One main problem in these experiments was the enumeration of cysts. Aliquots of the culture fluid did not contain the non-motile resting stages; in situ counting of cysts was impracticable since cells at the edges of culture dishes were hard to detect. As a consequence, it was not possible to record changes in numbers of algae, motile ciliates and cysts with time by repetitive enumeration in 1 culture. Instead, each experiment consisted of several parallel batch cultures started with identical material, which were assumed to develop simultaneously and which were terminated consecutively at $24 \mathrm{~h}$ intervals.

\section{Expt 1}

A dense culture of Pelagostrombidium fallax (60 ml) was decanted into a clean culture dish to separate motile stages from cysts attached to the dish. The 

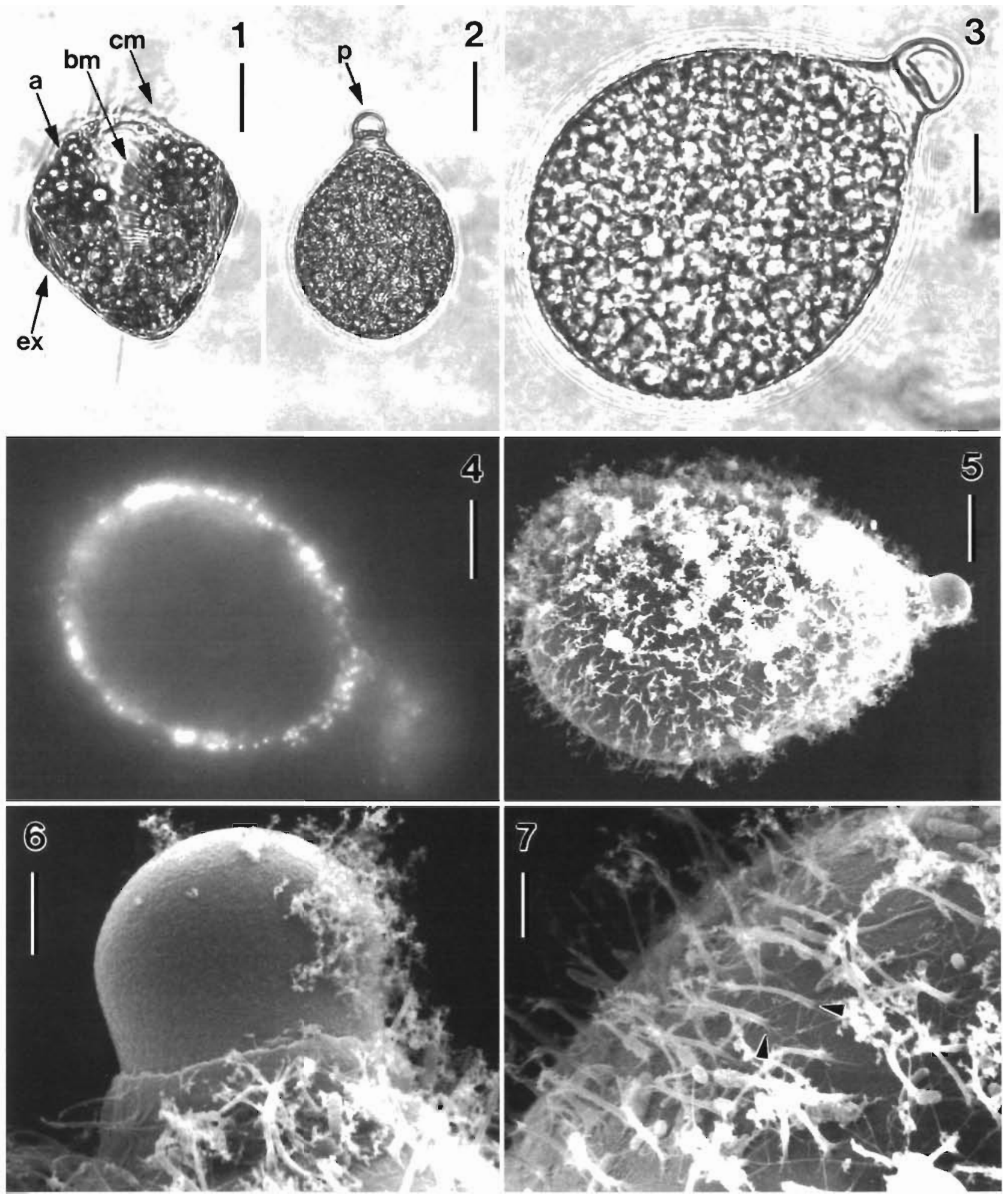

Figs. 1 to 7. Pelagostrombidium fallax. Characteristic features of motile stage and cyst. Fig. 1. Photomicrograph of a live motile specimen. bm: buccal adoral membranelles; cm: collar adoral membranelles, blurred due to rapid movement; ex: extrusome bundles; a: ingested algae. Figs. 2 \& 3. Photomicrograph of live cyst. p: papulla. Fig. 4. Cyst after vital staining with DAPI, viewed with epifluorescence microscopy, UV excitation. Bacteria on the cyst surface are recognized by their bright DAPI fluorescence. Fig. 5. SEM graph of cyst, partly covered with detritus. Fig. 6. SEM graph of papulla. Fig. 7. SEM graph of cyst surface, showing spines anchored on the cyst surface with fine fibres. Arrowheads point to the bases of 2 spines. Scale bars: Figs. $1 \& 2,20 \mu m$; Figs. 3 to $5,10 \mu \mathrm{m}_{\text {; Figs. } 6} \& 7,2 \mu \mathrm{m}$ 


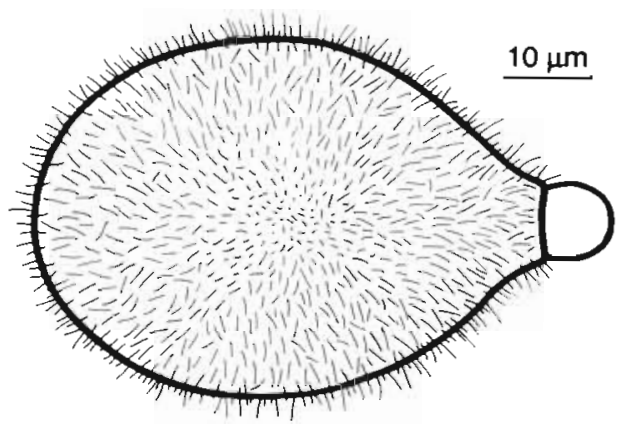

Fig. 8. Pelagostrombidium fallax. Schematic drawing of a cyst, combined from life and SEM

liquid, which contained only motile ciliates, was distributed into 24 wells of a cluster dish, with $2.5 \mathrm{ml}$ well ${ }^{-1}$. The contents of 3 wells were immediately collected and fixed with acid Lugol's solution. At intervals of $24 \mathrm{~h}$, additional batches of 3 wells were collected and fixed after detaching cysts by agitation with a Pasteur pipette. Of each sample, $2 \mathrm{ml}$ were filled into Sedgewick-Rafter chambers for enumeration of algae, motile ciliates and cysts. These data are shown in Fig. 9.
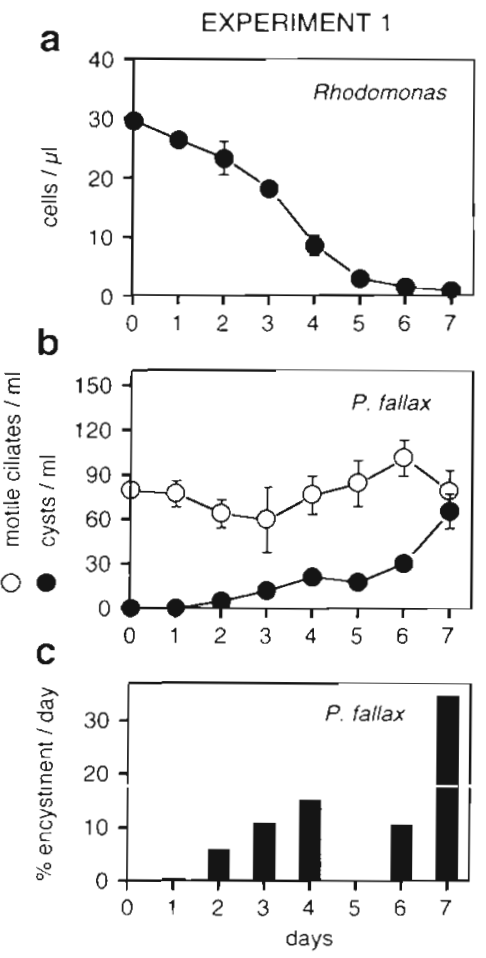

Fig. 9. Development of Rhodomonas sp. and Pelagostrombidium fallax during Expt 1 (a, b) Cell concentrations of algae, motile ciliates and cysts. Mean values and standard deviation of data obtained from 3 parallel batches. (c) Percentage of the motile ciliate population which had encysted within $1 \mathrm{~d}$ intervals (see text)
Initial concentrations were $79 \pm 3$ ciliates $\mathrm{ml}^{-1}$ and $30 \pm 1 \times 10^{3}$ Rhodomonas $\mathrm{sp}$. cells $\mathrm{ml}^{-1}$. During the experiment, food algae were grazed down to less than 1000 cells $\mathrm{ml}^{-1}$. Over the first $6 \mathrm{~d}, 30$ cysts $\mathrm{ml}^{-1}$ appeared, while motile ciliates increased to about 100 cells $\mathrm{ml}^{-1}$. From Day 6 to Day 7, an additional 35 cysts $\mathrm{ml}^{-1}$ were produced, whereas numbers of motile ciliates declined.

The percentage of the motile population which had encysted within $1 \mathrm{~d}$ intervals is also depicted in Fig. 9. This value was estimated as follows: for each day, numbers of new cysts per $m$ were calculated as the difference between cyst numbers recorded on this day and the highest number recorded earlier ('old cysts'). Negative values were set to zero with the assumption that no excystment occurred. Empty cysts with the plug removed, as described by Kim \& Tanaguchi (1995) for excysting strombidiid ciliates, were not observed. Subsequently, the percentage of the motile population which had encysted within $1 \mathrm{~d}$ was calculated according to:

$$
\% \text { encystment } \mathrm{d}^{-1}=\frac{\text { new cysts } \mathrm{ml}^{-1} \times 100}{\begin{array}{l}
\text { motile ciliates } \mathrm{ml}^{-1} \text { as recorded } \\
\text { on the preceding day }
\end{array}}
$$

Between Days 1 and 6 , this value varied between 0 and $15 \%$. Within the last $24 \mathrm{~h}, 35 \%$ of the motile population encysted. These data suggest that deficiency of food might be a major factor inducing encystment in Pelagostrombidium fallax. In a second experiment food concentrations were manipulated to test this hypothesis.

\section{Expt 2}

A similar protocol was followed as in Expt 1. A Pelagostrombidium fallax culture $(210 \mathrm{ml})$ was distributed into 56 wells of 12 -well cluster dishes, with $3.5 \mathrm{ml}^{\text {well }}{ }^{-1}$, while the rest of the culture was used to determine initial concentrations of algae and ciliates. This material served for 2 parallel experiments, A and B (28 wells each), of 14 d duration, with harvests of 2 wells series ${ }^{-1} \mathrm{~d}^{-1}$. Cell concentrations were determined as in Expt 1, except that $3 \mathrm{ml}$ sample ${ }^{-1}$ was scanned for motile ciliates and cysts. During the course of the experiment, food levels were manipulated by adding equal quantities of food algae to all wells belonging to 1 series.

The development of Pelagostrombidium fallax and Rhodomonas sp. in Expt 2 is depicted in Fig. 10. Both series $A$ and $B$ were started with identical inoculants. Initial concentrations were $48 \pm 6$ motile ciliates $\mathrm{ml}^{-1}$ and $28 \pm 2 \times 10^{3}$ algal cells $\mathrm{ml}^{-1}$. In order to compensate a decrease in food, series $A$ was supplemented with $10 \times 10^{3}$ Rhodomonas sp. $\mathrm{ml}^{-1} 1 \mathrm{~d}$ after the start. In contrast to Expt 1, algae grew in both series between 
EXPERIMENT 2 A
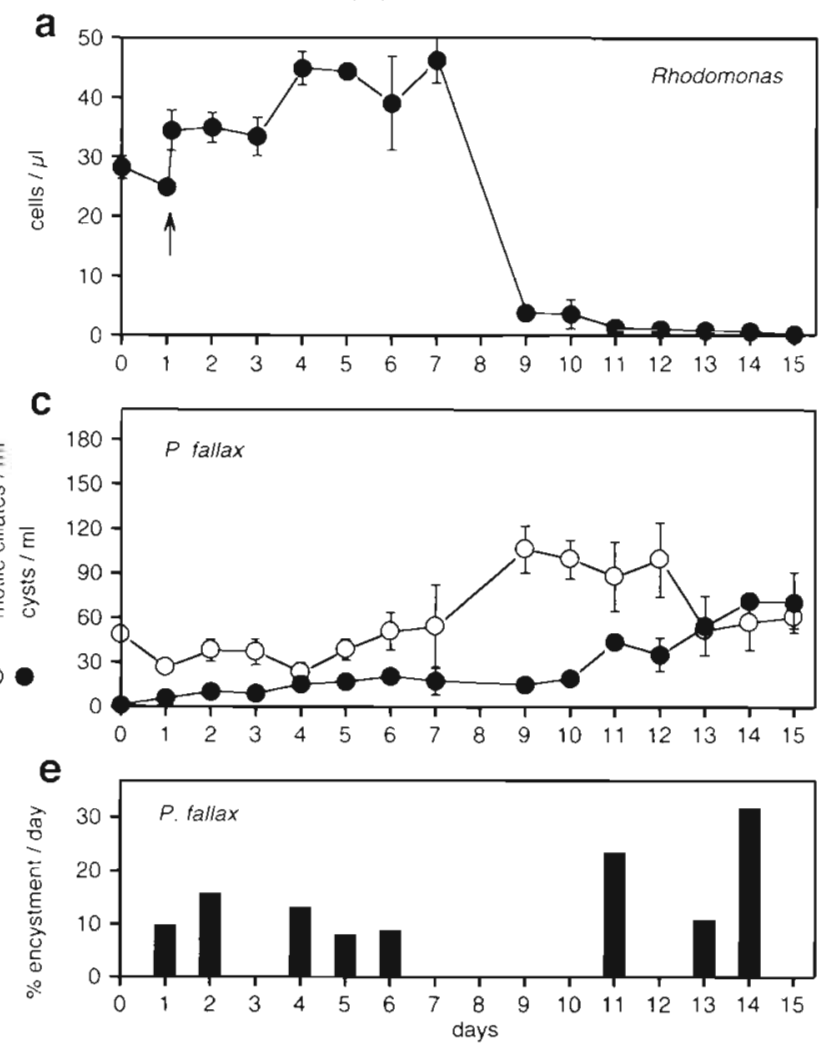

EXPERIMENT 2 B

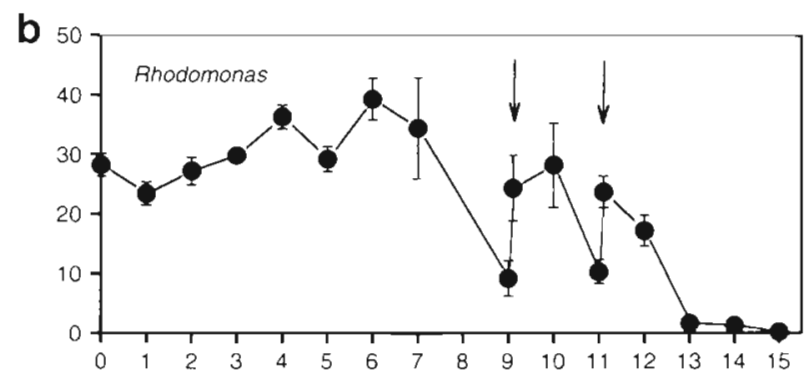

d

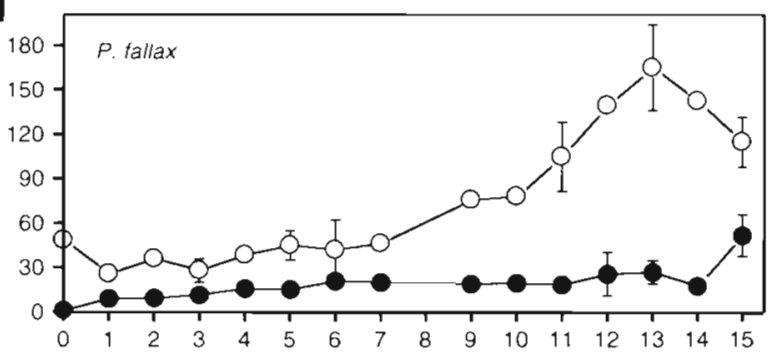

f

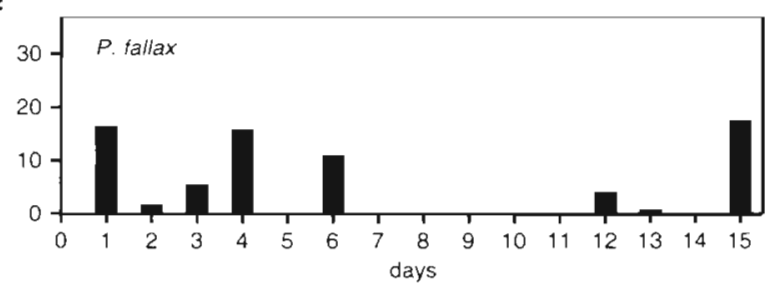

Fig. 10. Development of Rhodomonas sp. and Pelagostrombidium fallax during Expt 2. (a to d) Cell concentrations of algae, motile ciliates and cysts. Mean values and standard deviation of data obtained from 2 parallel batches. Arrows mark days when algae were added. (e, f) Percentage of the motile ciliate population which had encysted within $1 \mathrm{~d}$ intervals (see text)

Day 1 and Day 7. while numbers of motile ciliates remained fairly constant. Within the first week, between 0 and $16 \%$ of the ciliate population encysted per day.

Between Day 7 and Day 9, Rhodomonas sp. was grazed down to $\sim 4000$ cells $\mathrm{ml}^{-1}$ and $\sim 9000$ cells $\mathrm{ml}^{-1}$ in series $A$ and $B$, respectively. Food was added to series $B$ on Days 9 and 11, thus keeping the food level in these wells above $10 \times 10^{3}$ algae $\mathrm{ml}^{-1}$ until Day 12 . Ciliates in $\mathrm{A}$ increased until Day 9 ; the ciliate population in $B$ responded to addition of food on Days 9 and 11 with a prolonged growth phase until Day 13. In both series, cyst production ceased during population growth and recommenced after food had been reduced to $<4000$ cells $\mathrm{ml}^{-1}$. Final algal concentrations in both series were -300 cells $\mathrm{ml}^{-1}$.

The longest period of exponential growth of Pelagostrombidium fallax occurred between Day 7 and Day 13 in series $B$. The growth rate $(\mu)$ during this interval was $0.21 \mathrm{~d}^{-1}$; new cysts appearing on Days 12 and 13 were included in this calculation (Fig. 11).

Regarding the response of the ciliates to varying food levels in Expt 2 (Fig. 10) 3 different phases can be distinguished. (1) Periods of high food concentration, with low growth and grazing activities of the motile population and low percentage of encystment (A and B: Days 1 to 6). (2) Periods after initially high food concentration, with high growth and grazing activities of motile ciliates and virtually no encystment (A: Days 7 to 10 ; B: Days 7 to 14). (3) Periods after food had been depleted, with declining numbers of motile ciliates and a high percentage of encystment (A: Days 11 to 14; B: Day 15).

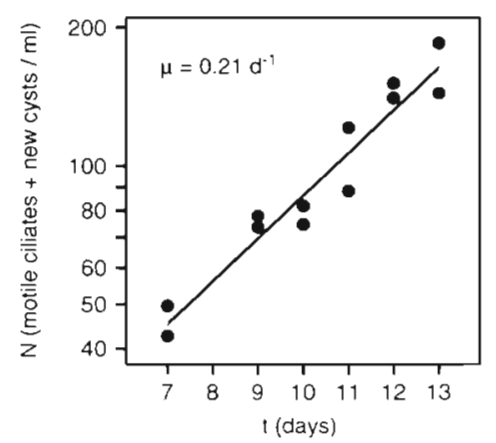

Fig. 11. Concentrations of motile ciliates as measured between Day 7 and Day 13 in Expt 2B. Straight line according to the equation: $\log N=1.01+0.093 t ; n=12, r^{2}=0.93$ 


\section{DISCUSSION}

The present study is the first description of a resting stage in a non-loricate oligotrich ciliate from the freshwater environment. The distinctive flask-shaped cysts of Pelagostrombidium fallax closely resemble resting stages described for 3 marine species: Strombidium oculatum (Fauré-Fremiet 1948), Strombidium conicum (Kim \& Tanaguchi 1995) and an oligotrich ciliate of uncertain identity (Reid 1987). Reid identified this species as Strombidium crassulum, whereas his illustrations show motile stages of a strobilidiid ciliate. Flask-shaped cysts, also known as 'papulifères', are typical for ciliates of the orders Oligotrichida and Heterotrichida (Reid \& John 1983). The protrusion or papulla marks the site where the excysting ciliate will emerge after rupture of the hyaline plug, as shown for $S$. conicum by Kim \& Tanaguchi (1995). Up to now, I have not observed excystment in my cultures of $P$. fallax. While the general shape of papulifères is rather uniform, different structures of cyst walls have been described (Reid \& John 1983). SEM graphs of the cyst surface of S. conicum show a network of fine fibres (Kim \& Tanaguchi 1995), whereas the cysts shown by Reid (1987) and the P. fallax cysts (this study) are ornamented with spines.

Growth rates of Pelagostrombidium fallax from Lake Constance have been measured previously by Müller \& Geller (1993). At $9^{\circ} \mathrm{C}$ and non-limiting food concentrations, they recorded growth rates $\left(\mu_{\max }\right)$ between 0.20 and $0.24 \mathrm{~d}^{-1}$, which agrees well with the value of $\mu=0.21 \mathrm{~d}^{-1}$ abserved in this study. Müller \& Geller (1993) did not report cyst formation of their P. fallax strain. Their experiments were performed in Erlenmeyer flasks, the bottom of which could not be examined with a stereomicroscope. When cultures were sampled in these experiments, care was taken to avoid vigorous shaking. Attached cysts, if present, were not transferred to the counting chambers by this procedure. Therefore, encystment may also have occurred during their study, but escaped attention due to the experimental design. One single observation of a cyst was recorded by A. Schone (unpubl.) during the study of Müller \& Geller (1993).

Müller et al. (1991) investigated the seasonal distribution of ciliate taxa in pelagic waters of Lake Constance over 3 annual cycles. Strombidid ciliates, including Pelagostrombidium fallax, were found regularly from mid-March through October, with mean concentrations at 0 to $8 \mathrm{~m}$ depth ranging from 0.3 to 3 cells $\mathrm{ml}^{-1}$. From November through mid-March, members of this group were found only sporadically. Mean concentrations in the same depth interval of suitable nanoplankton food, averaged over seasonal phases, were highest during the phytoplankton spring bloom (70 to $140 \mathrm{ng} \mathrm{C} \mathrm{ml-1}$ ) and lowest in winter ( 11 to $25 \mathrm{ng} \mathrm{C} \mathrm{ml}^{-1}$ ).
In the present study, encystment of Pelagostrombidium fallax was quantified in relation to prey abundance. Initial and final Rhodomonas sp. concentrations

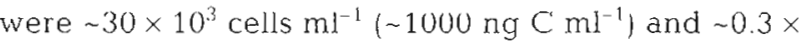
$10^{3}$ cells $\mathrm{ml}^{-1}\left(\sim 10 \mathrm{ng} \mathrm{C} \mathrm{ml} \mathrm{C}^{-1}\right)$, respectively. While the lower value was similar to the food level $P$. fallax experiences during the winter months, the higher value was far above prey concentrations observed in the lake. The results, as shown in Figs. $9 \& 10$, can be summarized as follows: Cyst formation occurred at high and low food levels. In any situation, only a fraction of the population encysted. Enhanced encystment occurred in all 3 series shortly after food had been grazed down to less than 4000 cells $\mathrm{ml}^{-1}$. This response could be delayed for $4 \mathrm{~d}$ in series $2 \mathrm{~B}$ relative to the parallel series $2 \mathrm{~A}$ by keeping algal concentrations high. Although these data do not reveal a simple relationship between encystment and prey abundance, they suggest that some dependency does exist betwoen these 2 parameters.

Fenchel (1987) discussed that responses of protozod to starvation might reflect the time scale of fluctuations in food resources in their natural environment. According to this hypothesis, cells will stay active if periods of starvation are likely to be short and encyst if extended starvation periods are expected.

Planktonic algivorous ciliates in Lake Constance are exposed to long and short starvation periods. During the growing season, distribution of suitable food is rather patchy in time and space. The most dramatic event is the breakdown of the spring bloom of small algae leading to a clear-water phase, which is variable in duration between different years (Gaedke \& Schweizer 1993). During winter, a long period of low algal concentrations occurs regularly. While encystment might be an adequate strategy to survive long periods without food, its risks are high for a planktonic ciliate in a deep lake, since sedimentation removes the cysts from the natural environment of the motile population, the pelagic zone. Obviously, the encysting cells must be in good nutritional state to have a chance for long-time survival after excystment in the sediment.

Considering these risks, it might be a suitable survival strategy for a planktonic population to routinely form a small number of cysts during periods of high food concentrations and a larger number as a response to decreasing food levels, while some individuals will always stay motile. This concept agrees with the data presented in this study and also offers an explanation for the apparent contradiction emphasized by Corliss \& Esser (1974) that deficiency of food as well as excess of food have been reported to induce encystment. It is also in accordance with observations of Paranjape (1980) on Helicostomella subulata, another planktonic oligotrich ciliate. In laboratory cultures, this marine 
tintinnid encysted and excysted under uniform environmental conditions in excess of food. Similar to Pelagostrombidium fallax in this study, only a fraction of the $H$. subulata population, approximately $50 \%$, encysted within 2 wk.

The hypothesis presented here needs to be tested by further experiments. Future studies should concentrate on: (1) additional factors which may encourage encystment of Pelagostrombidium fallax in culture; (2) factors inducing excystment; (3) the search for $P$. fallax resting cysts in water and sediment samples from Lake Constance in different seasons.

Acknowledgements. The contribution of J. Hentschel, who performed scanning electron microscopy, is gratefully acknowledged. I also thank C. Wünsch for skilled maintenance of stock cultures. W. Foissner, D. J. Montagnes and an anonymous reviewer offered constructive criticism on the submitted manuscript. This study was supported by the Deutsche Forschungsgemeinschaft within the Special Collaborative Program 'Cycling of Matter in Lake Constance' (SFB 248).

\section{LITERATURE CITED}

Corliss JO, Esser SC (1974) Comments on the role of the cyst in the life cycle and survival of free-living protozoa. Trans Am Microsc Soc 93:578-593

Fauré-Fremiet E (1948) Le rythme de marée du Strombidium oculatum Gruber. Bull Biol France-Belgique 82:3-23

Fenchel T (1987) Ecology of protozoa. Science Tech, Madison, WI

Foissner W (1994) Progress in taxonomy of planktonic freshwater ciliates. Mar Microb Food Webs 8:9-35

Gaedke U, Schweizer A (1993) The first decade of oligotrophication in Lake Constance. I. The response of phytoplankton biomass and cell size. Oecologia 93: 268-275

Giani A (1991) Implications of phytoplankton chemical composition for zooplankton production: experimental evidence. Oecologia 87:409-416

Responsible Subject Editor: K. Simek, České Budèjovice, Czech Republic
Jonsson PR (1994) Tidal rhythm of cyst formation in the rock pool ciliate Strombidium oculatum Gruber (Ciliophora, Oligotrichida): a description of the functional biology and an analysis of the tidal synchronization of encystment. J Exp Mar Biol Ecol 175:77-103

Kim YO, Tanaguchi A (1995) Excystment of the oligotrich ciliate Strombidium conicum. Aquat Microb Ecol 9:149-156

Krainer KH (1991) Contributions to the morphology, infraciliature and ecology of the planktonic ciliates Strombidium pelagicum n. sp., Pelagostrombidium mirabile (Penard, 1916) n. g., n. comb., and Pelagostrombidium fallax (Zacharias, 1896) n. g., n. comb. (Ciliophora, Oligotrichida). Eur J Protistol 27:60-70

Müller H, Geller W (1993) Maximum growth rates of aquatic ciliated protozod: the depencence on body size and temperature reconsidered. Arch Hydrobiol 126:315-327

Müller $H$, Schöne A, Pinto-Coelho RM, Schweizer A, Weisse $T$ (1991) Seasonal succession of ciliates in Lake Constance. Microb Ecol 21:119-138

Paranjape MA (1980) Occurrence and significance of resting cysts in a hyaline tintinnid, Helicostomella subulata (Ehre.) Jørgensen. J Exp Mar Biol Ecol 48:23-33

Reid PC (1987) Mass encystment of a planktonic oligotrich ciliate. Mar Biol 95:221-230

Reid PC, John AWG (1978) Tintinnid cysts. J Mar Biol Ass UK 58:551-557

Reid PC, John AWG (1983) Resting cysts in the ciliate class Polyhymenophorea: phylogenetic implications. J Protozool 30:710-713

Smetacek V (1984) Growth dynamics of a common Baltic protozooplankter: the ciliate genus Lohmanniella. Limnologica $15: 371-376$

Sorokin YI, Paveljeva EB (1972) On the quantitative characteristics of the pelagic ecosystem of Dalnee lake (Kamchatka). Hydrobiologia 40:519-552

Strathmann RR (1967) Estimating the organic carbon content of phytoplankton from cell volume or plasma volume. Limnol Oceanogr 12:411-418

Weisse T, Müller H, Pinto-Coelho R, Schweitzer A, Springmann D, Baldringer G (1990) Response of the microbial loop to the phytoplankton spring bloom in a large prealpine lake. Limnol Oceanogr 35:781-794

Manuscript first received: August 8, 1996

Revised version accepted: October 16, 1996 